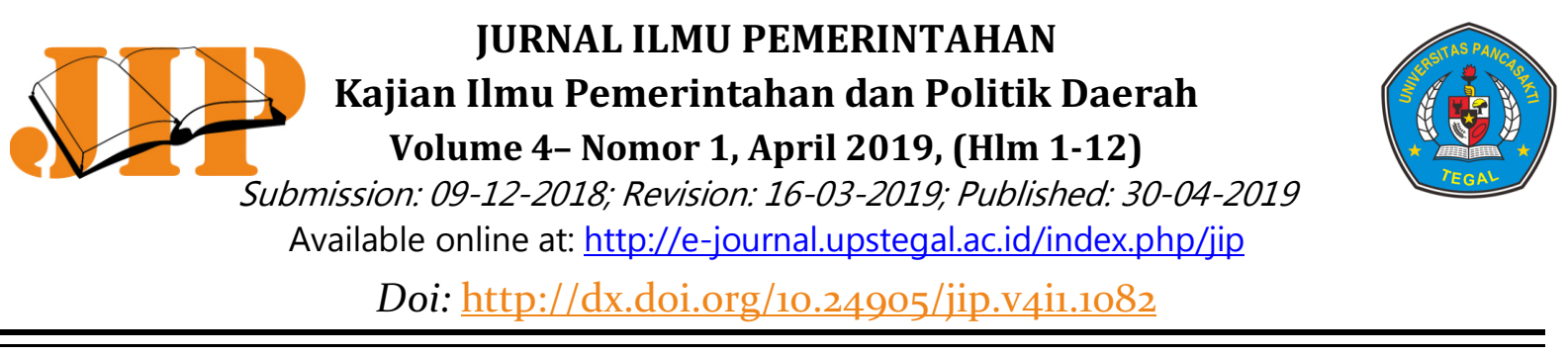

\title{
Relokasi Pekerja Seks Komersial setelah Penutupan Lokalisasi Kedung Banteng
}

\author{
Dian Suluh Kusuma Dewi 1) *, Yusuf Adam Hilman 2) \\ 1,2 Program Studi Ilmu Pemerintahan, Universitas Muhammadiyah Ponorogo. Jalan Budi Utomo \\ No. 10 Ronowijayan, Siman, Kabupaten Ponorogo, Jawa Timur, 63471 Indonesia. \\ * Korespondensi Penulis. E-mail: 545471adamongis@gmail.com
}

\begin{abstract}
Abstrak
Penutupan lokalisasi bukanlah perkara mudah, sehingga memerlukan upaya yang berkesinambungan yang memadukan sinergitas berbagai lembaga pemerintah, masyarakat dan juga Non Government Organization. Kajian ini bertujuan untuk mengupas teknis penutupan lokalisasi kedung banteng, yang menjadi lokalisasi ke 46 yang secara resmi ditutup, bagaimanakah langkah - langkah strategisnya. Kajian ini menggunakan metode penelitian diskriptif, dengan menganalisis data primer dan sekunder, berupa observasi, dokumentasi, dan hasil wawancara. Proses penutupan dilakukan setelah terbit beberapa aturan hukum. Secara umum proses penutupan telah selesai, namun kemudian muncul beberapa persoalan terkait keberadaan eks pekerja seks komersial yang sulit untuk dikendalikan, karena beberapa program dianggap tidak efektif. fakta di lapangan banyak sekali persoalaan yang belum selesai, terkait dana kompensasi yang diberikan kepada eks - pekerja seks komersial selain jumlahnya yang tidak sama, para pekerja tersebut merasa dana yang diberikan sangat minim, walaupun demikian proses penutupan lokalisasi sudah berhasil dilaksanakan. Secara sosiologis kebijakan tersebut berpengaruh terhadap masyarkaat sekitar dan juga para eks pekerja komersil yang memulai hidup \& usaha baru demi kelangsungan hidupnya.
\end{abstract}

Kata kunci: Pekerja Seks Komersial; Pemberdayaan Perempuan

\section{Relocation Prostitutes After Closing Localization Kedung Banteng}

\begin{abstract}
Closing localization is not an easy matter, so it requires a continuous effort that combines the synergy of various government institutions, the community and also Non Government Organization. This study aims to explore the technical closure of kedung banteng, which became the 46th localization which was officially closed, how are the strategic steps. This study uses descriptive research methods, by analyzing primary and secondary data, in the form of observation, documentation, and interview results. The closing process is carried out after the issuance of several legal regulations. In general the closure process has been completed, but then some problems arise regarding the existence of ex-commercial sex workers that are difficult to control, because some programs are considered ineffective. there are many unresolved facts on the ground, related to the compensation funds given to ex-commercial sex workers in addition to the amount that is not the same, the workers feel that the funds provided are very minimal, even though the closure process has been successfully implemented. Sociologically, this policy affects the surrounding community and also the former commercial workers who start a new life \& business for their survival.
\end{abstract}

Keywords: Prostitute; Women Empowerment 


\section{Dian Suluh Kusuma Dewi 1) *, Yusuf Adam Hilman 2)}

\section{PENDAHULUAN}

Prostitusi atau yang dikenal dengan pelacuran adalah sebuah usaha memperjual belikan kegiatan seks diluar nikah dengan imbalan materi (Supriyadi Widodo Eddyono, Rio Hendra 2017).

Pelacuran berasal dari bahasa Latin yaitu pro-stituere atau pro-stauree yang berarti membiarkan diri berbuat zina, melakukan persundalan, percabulan, dan pergendakan. Sehingga pelacuran atau prostitusi bisa diartikan sebagai perjualan jasa seksual, seperti oral seks atau hubungan seks untuk uang. Pelacur wanita disebut prostitue, sundal, balon, lonte; sedangkan pelacur pria disebut gigolo (Irwandy Samad 2012).

Pelacuran merupakan masalah sosial tertua yang dikenal masyarakat, dan erat sekali kaitannya dengan masalah perekonomian. Pelacuran dipandang sebagai gejala patologis karena melanggar norma agama, sosial dan hukum serta merupakan salah satu bentuk penyakit masyarakat yang harus dihentikan penyebarannya tanpa mengindahkan usaha pencegahan dan perbaikannya (Gunawan Prakoso, Ani Purwanti 2016).

Persoalan prostitusi di Indonesia tidak hanya perkara moralitas masyarakat, akan tetapi banyak aspek yang melatarbelakangi prilaku tersebut, seperti, faktor ekonomi, faktor psikologis, hingga faktor gaya hidup masyarakat, tetapi banyak orang bersepakat bahwa aktifitas tersebut dianggap tidak baik dan juga dilarang oleh agama dan konstitusi.

Motif melacur adalah motif berkuasa, yang terbentuk dari proses individual dan proses lingkungan. Secara individual, individu memaknai pelacuran sebagai cara memenuhi aspirasi ekonomi dan mendapatkan pembenaran tak langsung dari pemaknaan subjektif terhadap keyakinan Agama. Pemaknaan individual tersebut mendapat penguatan eksternal, yaitu dukungan sosial, berupa penghormatan terhadap pelacur. (Permadi 2015)

Alasan seseorang yang berprofesi sebagai wanita tunasusila adakalanya karena terpaksa (faktor eksternal) missalnya karena himpitan ekonomi, sulitnya mencari pekerjaan, terjebak oleh tipuan agen tenaga kerja, dan lain-lain. Selain itu, ada pula yang melakukannya karena kemauan sendiri (faktor internal). Bagi yang sudah terlanjur berbuat, biasanya berpendapat sudah tidak ada lagi yang dapat dibanggakan dalam dirinya, maka ia akan mencari pelampiasan untuk tetap melakukan perbuatan amoralnya itu (Hasneli 2015).

Upaya-upaya konkrit sudah dilakukan oleh berbagai pihak, guna menuntaskan persoalan prostitusi, dari pihak pemerintah, masyarakat, Non Government Organitation (NGO), juga telah banyak dilakukan melalui berbagai metode dan juga pendekatan.

Konsep lokalisasi juga sudah pernah dilakukan oleh pemerintah dengan tujuan untuk meminimalisir dampak serta efek dari adanya praktik prostitusi, namun setelah muncul lokalisasi ternyata masih banyak persoalan-persoalan yang timbul, dan menjadikan praktik prostitusi semakin tinggi.

Lokalisasi merupakan sebuah bentuk usaha untuk mengumpulkan segala macam aktivitas / keiatan pelacuran dalam satu wadah, yang dianggap sebagai kebijakan lokalisasi pelacuran (Nida Issabela 2010).

Resosialisasi pelacur ternyata telah gagal mengemban fungsinya sebagai 


\section{Dian Suluh Kusuma Dewi 1) *, Yusuf Adam Hilman 2)}

sarana rehabilitasi sosial para pelacur. Mengingat bahaya membubarkan resosialisasi jauh lebih besar jika dibandingkan dengan dipertahankannya resos, maka resosialisasi pelacur hingga saat ini masih diperlukan. Hanya saja, agar dapat mencapai tujuan rehabilitasi, sistem resosialisasi yang ada pada saat ini perlu diperbaiki dan dikembangkan secara lintas sektoral baik dari segi pengelolanya, maupun obyek yang dikelola. Mengingat masalah pelacuran sangat pelik dan komplek serta belum adanya satu wadah yang terintegrasi dalam menangani masalah pelacuran, penulis memandang perlu dibentuk suatu badan di bawah koordinasi Menteri Koordinator Kesejahteraan Rakyat. Badan tersebut adalah Badan Koordinasi Penanganan Masalah Pelacuran (BKPMP) yang penyelenggaraannya Dapat dilakaukan baik di tingkat pusat, provinsi atau regional (Miwa Patnani 1999).

Peranan Negara dalam upaya menyelesaikan persoalan prostitusi, dengan cara merancang konsep lokalisasi menjadi sebuah kebijakan yang kontroversi, mengingat pembangunan lokalisasi lebih menekankan pada pemusatan kegiatan prostitusi dalam sebuah kawasan untuk meminimalisasi dampak yang ditimbulkan, akan tetapi konsep memanusiakan manusia tidak terlihat, karena para penjaja seks komersial (PSK) lebih diposisikan sebagai pesakitan bukan pada individu yang dilibatkan dalam penanggulangan masalah prostitusi, sehingga para PSK tidak memiliki motivasi untuk keluar dari dunia hitam itu.

Peran Lembaga swadaya Masyarakat atau NGO telah melakukan berbagai upaya, namun upaya tersebut berdimensi sempit, karena hanya aspek individual atau personal dari PSK tidak melibatkan kelembagaan pemerintahan, dah upaya tersebut bukan bertujuan untuk menuntaskan persoalan yang ada, tetapi lebih pada pendampingan dan pemberdayaan para PSK supaya memiliki ketrampilan yang bisa menunjang kehidupan sehari - hari nya.

Peran serta Lembaga Swadaya Masyarakat (LSM) menjadi hasil temuan dari penelitian ini karena pemberdayaan yang dilakukan oleh LSM Gerakan Melukis Harapan (GMH) cukup besar dan hampir menyeluruh dalam berbagai aspek seperti ekonomi, pendidikan, kesehatan dan wanita harapan dimana LSM GMH ini sangat berusaha dalam menciptakan image baru yang lebih positif dan merubah image negatif kawasan exlokalisasi Dolly dengan cara memetakan warga terdampak ke dalam kampoengkampoeng harapan dimana salah satunya adalah warga terdampak di RW IV yang menjadi sasaran untuk dijadikan sentra oleh-oleh dengan produk yang diberi nama Samijali (Dita Fatika Sari 2011).

Pelaksanaan pemberdayaan PSK dari beberapa lokalisasi di Kabupaten Malang, telah berhasil mengentaskan mengentaskan 34 PSK dari profesinya dari jumlah total 66 PSK. Para PSK yang telah keluar dari lokalisasi, dikembalikan ke keluarganya masing-masing. Pemberdayaan masih berlanjut dengan cara pemantauan dan komunikasi dari Dinas Sosial dengan mantan PSK sampai 5 bulan berikutnya. Hal ini dilakukan untuk mengetahui perkembangan kondisi mantan PSK tersebut agar benar- benar sadar dan tidak kembali ke profesi lamanya (Ati et al. 2015).

Tidak semua perangkat desa dan pegawai kecamatan mengetahui ke- 


\section{Jurnal Ilmu Pemerintahan: Kajian Ilmu Pemerintahan dan Ilmu Politik, 4 (1), April \\ $2019-4$}

Dian Suluh Kusuma Dewi 1) *, Yusuf Adam Hilman 2)

beradaan warung kopi berpotensi menjalankan aktifitas seks bebas atau komersil, meskipun perangkat desa dan pegawai kecamatan mengakui keberadaan tempat tersebut, namun beliau akan memberikan teguran jika masyarakat merasa terganggu kenyamanannya. Sedangkan masyarakat menerima keberadaan warung kopi tersebut karena tidak memberikan kerugian. Tindakan ingindalian yang selama ini dilakukan untuk mengendalikan peningkatan seks bebas melalui warung kopi adalah kegiatan patroli yang merupakan tugas rutin perangkat desa dan kecamatan. Dalam pelaksanaannya, perangkat desa dan kecamatan bekerjasama dengan lembaga sederajat seperti polsek dan koramil. Petugas akan memberikan sanksi kepada pekerja dan pengunjung warung kopi berdasarkan peraturan daerah yang ada jika ditemukan pelanggaran Perda. Kemudian seusai pelaksanaan patroli, perangkat desa dankecamatan melakukan pelaporan secara lisan ataupun tulisan (Arista et al. 2017).

Upaya yang dilakukan oleh Negara dalam hal ini pemerintah dan juga Lembaga Swadaya Masyarakat atau Non Government Organization, terkesan berjalan sendiri-sendiri, sehingga terlihat kurang efektif, karena proses normalisasi kehidupan Pekerja Seks Komersial, membutuhkan waktu dan penerimaan masyarakat sekitar terhadap mantan pekerja tersebut.

Kegagalan-kegagalan upaya yang dilakukan berbagai pihak, seperti: Pemerintah, masyarakat dan LSM atau NGO, kemudian memberikan inisiasi dari Pemerintahan Provinsi Jawa Timur untuk membuat kebijakan tentang penanggulangan masalah prostitusi, hingga melahirkan produk hukum, berupa: Surat Gubernur (SK) Gubenur Jawa Timur dalam bentuk instruksi tanggal 30 November 2010 No: 460/16474/031/ 2010, perihal pencegahan dan penanggulangan prostitusi, serta women trafficking. Kemudian dilanjutkan dengan SK tanggal 20 Oktober 2011, No: 460/031/2011; Perihal Penanganan Lokalisasi WTS di Jawa Timur.

Perjalanan pajang tersebut dalam rangka memperkuat kelembagaan pemerintah dalam hal penyelesaian masalah prostitusi, khususnya yang ada di Provinsi Jawa Timur, akhirnya membuahkan hasil dimana tercatat, bahwa "Data dari tahun 2011, ada sebanyak 47 lokalisasi di Jatim, semuanya sudah ditutup, dan terakhir tahun 2016 ini di Kota Mojokerto," (Zen Arivin. 2016).

Jumlah tersebut memang sangat mencengangkan, selain dari jumlahnya yang sangat banyak, persebaraanya juga merata, tentunya dampaknya juga sangat luas, selain menimbulkan persoalan norma dan susila, juga berdampak pada bidang kesehatan, ekonomi, sosial, dan budaya.

Provinsi Jawa Timur sendiri merupakan wilayah dengan Jumlah Kabupaten/kota yang paling banyak di Indonesia, jika kita analogikan, terkait keberadaan lokalisasi, lumrah jika angka nya mencapai 47, karena banyak nya kabupaten/kota di provinsi tersebut, dan hampir bisa kita jumpai, minimal satu lokalisasi di tiap wilayah nya, hal ini tentunya sangat menggangu citra suatu daerah, karena keberadaan lokalisasi, selain itu hal ini memberikan gambaran kepada seluruh elemen untuk berupaya menyelesaikan persoalan tersebut. 
Dian Suluh Kusuma Dewi 1) *, Yusuf Adam Hilman 2)

Berbagai upaya yang telah dilakukan, seperti penjelasan diatas pada akhirnya membuahkan hasil manis, karena telah berhasil menutup sekitar 47 lokalisasi yang tersebar di seluruh Kabupaten dan Kota yang ada di Provinsi tersebut.

Diawali dengan upaya - upaya konkrit dari berbagai pihak, akhirnya di tahun 2016 Jawa Timur menyatakan telah bersih dari praktik prostitusi yang ada di lokalisasi, hal ini sangat menarik mengingat masih banyak daerah yang kesulitan dalam menyelesaikan persolaan serupa, sehingga kami merasa tertarik untuk melakukan kajian, terkait bagaimana kebijakan penutupan lokalisasi itu bisa terlaksana.

Khusus untuk Kabupaten Ponorogo setelah muncul instruksi Gubernur kemudian, Bupati membuat aturan yang tertuang dalam Peraturan Bupati Nomor 1 Tahun 2015 tentang penutupan Lokalisasi WTS di Desa Kedung Banteng, Kecamatan Sukorejo, Kabupaten Ponorogo, setelah itu kemudian dilakukan beberapa tahapan untuk menindaklanjuti produk hukum di level daerah, sebagai payung hukum untuk pelaksanaan penutupan lokalisasi "Kedung Banteng", untuk segera dilaksanakan, akhirnya pada tanggal 8 Juni 2015 secara simbolis Lokalisasi tersebut resmi ditutup oleh Menteri Sosial Khofifah Indarparawangsa, dan kemudian dilanjutkan pada tanggal 11 April 2016 dilakukan pembongkaran lokalisasi yang dipimpin langsung oleh Bupati Ipong Muchlison.

Lokalisasi Kedung Banteng di Desa Kedung Banteng, Kecamatan Sukorejo, Ponorogo akhirnya resmi ditutup. Penutupan ini ditandai dengan Deklarasi Penutupan Lokalisasi berupa pembacaan
Ikrar Ponorogo Bersih dari Prostitusi. Pembacaan ikrar yang dipimpin oleh Ketua MUI Ponorogo ini ditirukan oleh seluruh penghuni lokalisasi, baik PSK maupun mucikari; para warga sekitar serta seluruh tamu yang hadir, termasuk Menteri Sosial Khofifah Indar Parawansa (Dili Eyato. 20015).

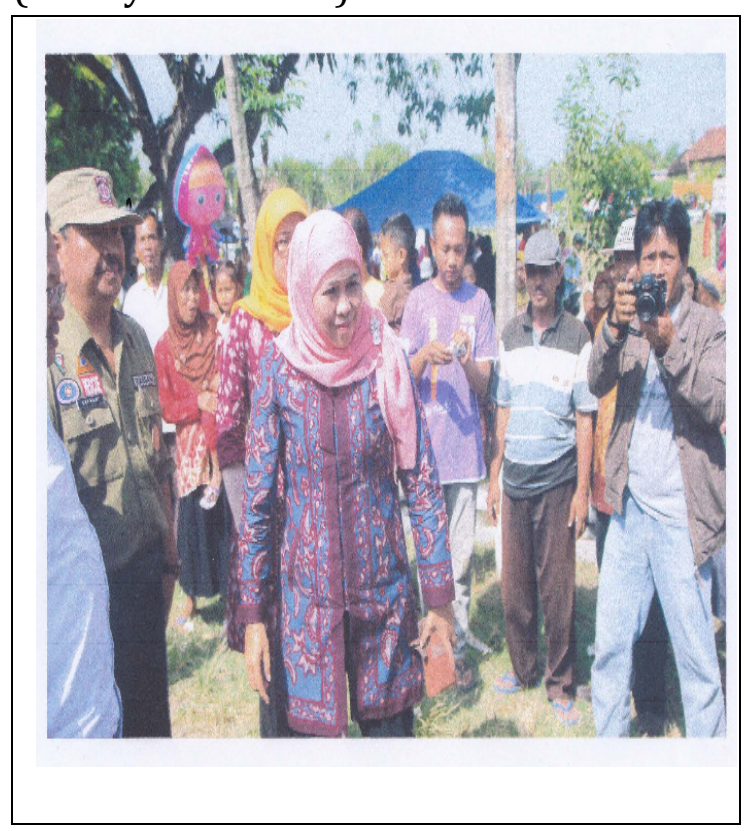

Gambar 1. Peresmian Penutupan Lokalisasi Kedung Banteng oleh Menteri Sosial Khofifah Indar Parawangsa.

Setiap kebijakan yang telah dibuat dan dilaksanakan menurut Islamy akan membawa dampak tertentu terhadap kelompok sasaran, baik yang positif (intended) maupun yang negatif (unintended). Ini berarti bahwa konsep dampak menekankan pada apa yang terjadi secara aktual pada kelompok yang ditargetkan dalam kebijakan. Jadi, dengan melihat konsekuensi dari dampak maka dapat dijadikan sebagai salah satu tolak ukur keberhasilan implementasi kebijakan dan juga dapat dijadikan sebagai masukan dalam proses perumusan kebijakan yang akan meningkatkan kualitas kebijakan tersebut. (M. Zainuddin 2016) 
Dian Suluh Kusuma Dewi 1) *, Yusuf Adam Hilman 2)

Keberhasilan menutup lokalisasi "Kedung Banteng” bagi kami itu menarik untuk dikaji, khususnya terkait dengan pelaksanaan kebijakan penutupan lokalisasi, pada uraian diatas telah digambarkan tentang proses penutupan lokalisasi dari awal hingga akhir, sehingga kami berusaha memfokuskan kajian pada pelaksanaan kebijakan terkait penutupan lokalisasi hingga dampak sosiologis bagi masyarakat.

\section{METODE}

Jenis penelitian yang digunakan adalah kualitatif deskriptif, penelitian ini dilakukan di lokalisasi kedung banteng kabupaten Ponorogo, subyek penelitian adalah proses penutuan lokalisasi tersebut, data yang dikumpulkan berupa data hasil wawancara dari beberapa pihak yang terkait. Analisis yang dilakukan peneliti yakni dampak sosiologis masyarakat setelah penutupan lokalisasi.

\section{HASIL DAN PEMBAHASAN}

\section{Landasan Hukum Kebijakan Penutupan Lokalisasi}

Dasar kebijakan penutupan lokalisasi kedung banteng memiliki dasar hukum pelaksanaan, yakni beberapa aturan hukum baik di level provinsi hingga daerah, yang tertuang dalam lembaran Negara sebagai berikut.

1) Surat Gubernur (SK) Gubenur Jatim yang telah dalam instruksi tanggal 30 November 2010 No: 460/16474/031/ 2010 , perihal pencegahan dan penanggulangan prostitusi, serta woman trafficking.

a) Menutup tanpa merelokasi Lokalisasi WTS dan tempat-tempat di curigai sebagai tempat terselubung yang ada di wilayah saudara, dengan melibatkan elemen masyarakat (Para Ulama, Da'I, Tokoh Masyarakat, PKK, TKSK dan Dunia Usaha serta lembaga Kesejahteraan Sosial) dan berkoordinasi dengan Kapolres serta Kodim setempat paling lambat akhir tahun 2014.

b) Melakukan perubahan nilai, sikap dan perilaku bagi para WTS dan Eks WTS melalui pembinaan mental spiritual dan pelatihan keterampilan sebelum dan setelah berada di wilayah asal mereka serta melakukan proses percepatan alih fungsi Eks Lokalisasi WTS menjadi sentra Usaha Ekonomi Baru dan fasilitas umum lainnya.

c) Membangun kerjasama yang harmonis antar daerah dalam upaya penanganan Lokalisasi WTS, utamanya daerah yang menjad tujuan WTS (Lokalisasi tempat beroperasi para WTS) dan daerah asal para WTS serta menciptakan lapangan kerja alternatif dan memprioritaskan program penanganan kemiskinan di wilayah /Desa asal WTS.

d) Untuk mendukung pelaksanaan penanganan dan pasca penutupan Lokalisasi WTS di harapkan agar segera merumuskan Instruksi Bupati/Walikota dan Peraturan Daerah yang dapat memberikan Solusi dan jaminan kepastian hukum terhadap penanganan dan pasca penutupan Lokalisasi WTS d wilayah sodara.

Instruksi Gubernur di atas beserta pointnya merupakan landasan hukum pokok yang harus dijalani dan dipenuhi 
Jurnal Ilmu Pemerintahan: Kajian Ilmu Pemerintahan dan Ilmu Politik, 4 (1), April

2019 - 7

Dian Suluh Kusuma Dewi 1) *, Yusuf Adam Hilman 2)

baik saat proses berjalannya maupun pasca penutupan

2) SK tanggal 20 Oktober 2011, No: 460/031/2011; Perihal Penanganan Lokalisasi WTS di Jawa Timur.

3) Peraturan Bupati Nomor 1 Tahun 2015 tentang penutupan Lokalisasi WTS di Desa Kedung Banteng, Kecamatan Sukorejo, Kabupaten Ponorogo

\section{Profile Lokalisasi Kedung Banteng}

Lokasi dari Lokalisasi Kedung Banteng, terletak di desa Kedung Banteng, Kecamatan Sukorejo, Kabupaten Ponorogo Provinsi Jawa Timur.

Jumlah PSK semakin menurun dari 201 menjadi 179 PSK dengan 36 mucikari, menurut hasil pendataan pemerintah setempat, para PSK berasal dari berbagai daerah, seperti Ngawi, Tulungagung, Magetan, Kediri, dan Ponorogo sendiri. (Achmad Faizal. 2015)

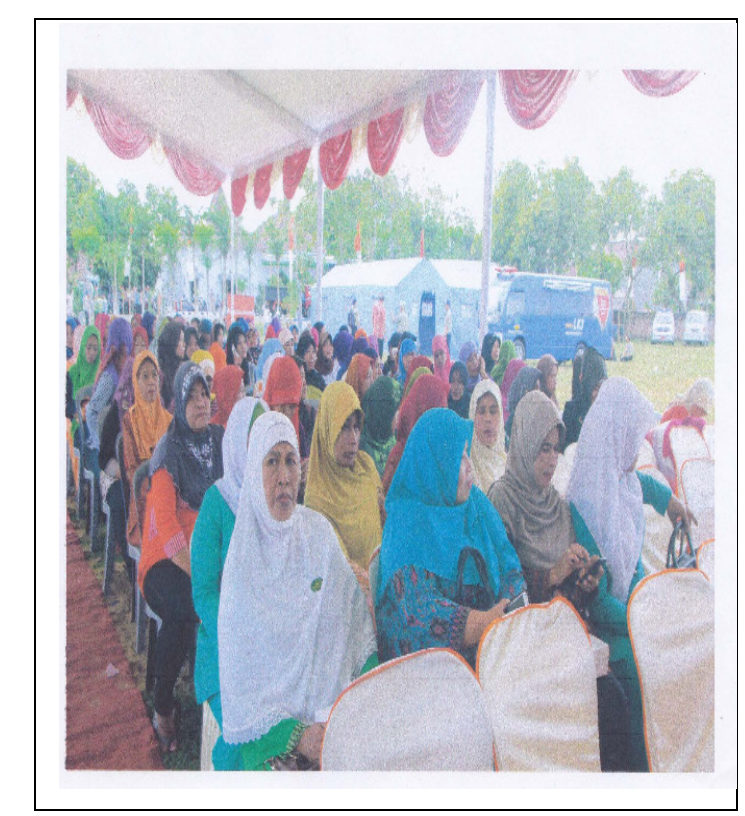

Gambar 2. Kondisi Eks - Pekerja Seks Komersial di Lokalisasi Kedung Banteng.
Tindak Lanjut Terhadap Kebijakan Penutupan lokalisai di Provinsi Jawa Timur.

Pemerintah Kabupaten Ponorogo melalui Dinas Sosial kemudian melakukan beberapa tahapan, untuk melakukan tindak lanjut kebijakan yang telah dibuat, yaitu sebagai berikut:

\section{1) Tahap Indetifikasi}

Tahapan ini dilakukan terhadap para WTS dan Mucikari sesuai dengan Nama, Daerah, asal serta status yang bersangkutan dengan maksud, untuk mempermudah dalam hal pelaksanaan koordinasi dengan instansi terkait pada saat pemulangan ke daerah asalnya.

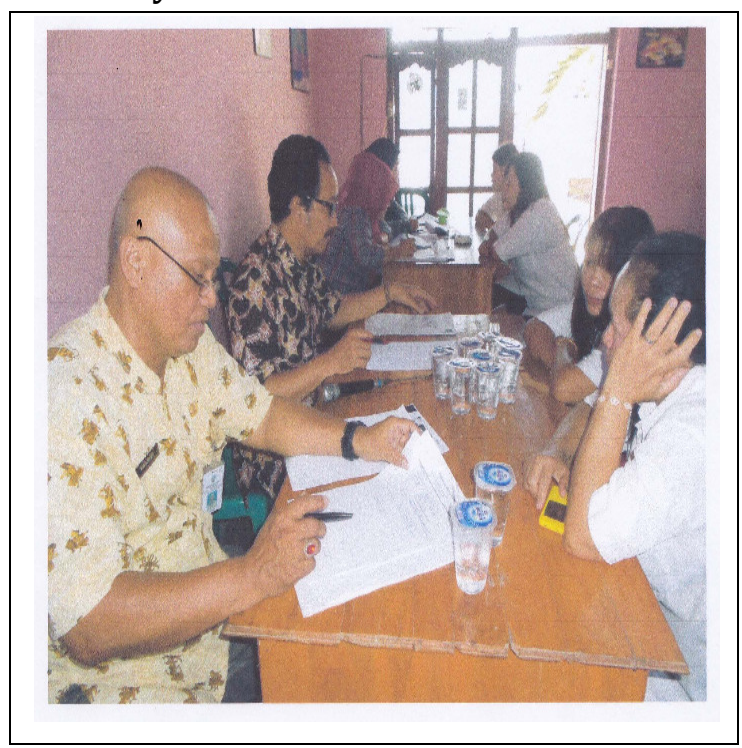

Gambar 3. Identifikasi Eks - Pekerja Seks Komersial di Lokalisasi Kedung Banteng.

\section{2) Tahapan Sosialisasi dan Koordinasi}

a) Sebagai langkah awal penutupan lokalisasi dilaksanakan tahap sosialisasi kepada pawa WTS dengan materi penyampaian tentang pemberian hak serta kewajiban para penghuni Lokalisasi yang konteknya adalah penutupan Lokalisasi Kedung Banteng. 
Jurnal Ilmu Pemerintahan: Kajian Ilmu Pemerintahan dan Ilmu Politik, 4 (1), April

$2019-8$

Dian Suluh Kusuma Dewi 1) *, Yusuf Adam Hilman 2)

b) Untuk menjaga kemungkinkan agar dikemudian hari tidak terjadi gejolak masyarakat yang tidak diinginkan maka perlu ditindaklanjuti dengan langkah koordinasi dengan Dinas / Instansi/ Lembaga / terkait yang terdiri dari unsur pemerintah, tokoh masyarakat, tokoh agama, kalangan akademis, serta elemen lain yang dianggap perlu guna menentukan langkahlangkah strategis pelaksanaan program.

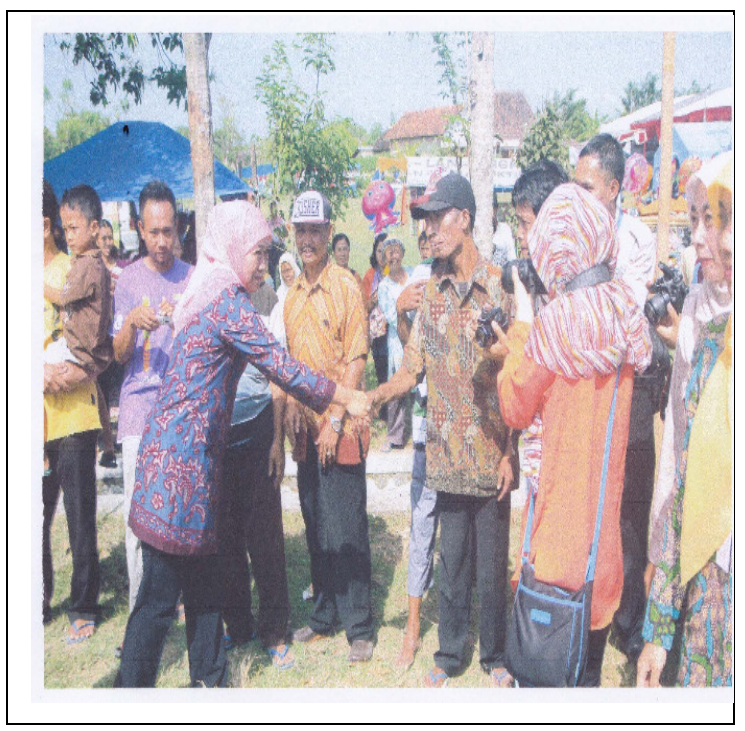

Gambar 4. Sosialisasi Penutupan Lokalisasi Kedung Banteng.

\section{3) Tahap Pemberdayaan}

Pelaksanaan tahap pemberdayaan diberikan materi perberdayaan di bidang Ekonomi dan Mental Spiritual (Agama Islam) yang pelaksanaannya dilakukan kerjasama dengan instansi terkait, waktu pembinaannya diselenggarakan setiap hari Kamis pukul 09.00 WIB sampai selesai.

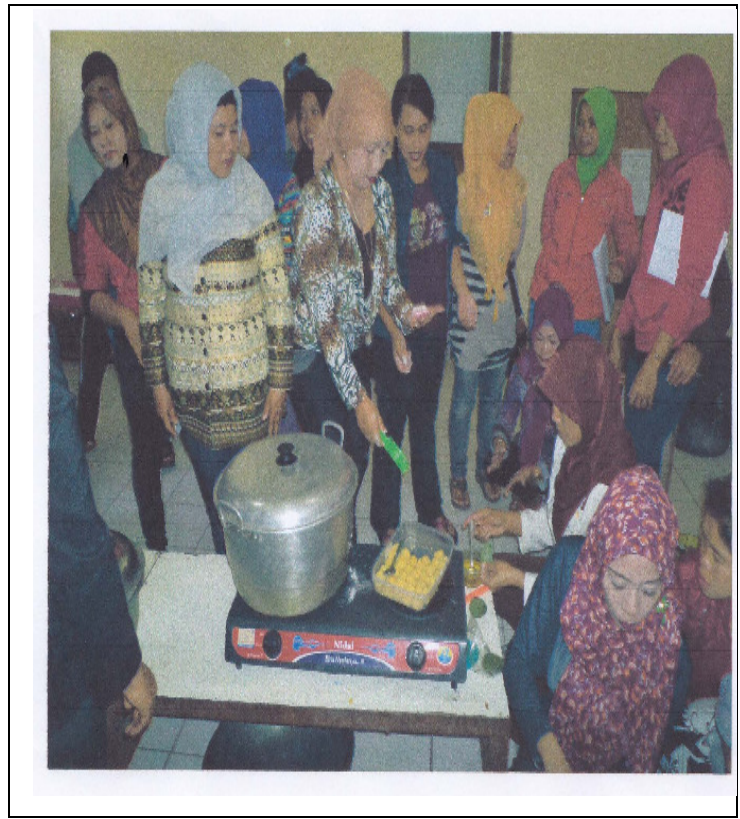

Gambar 5. Pemberdayaan Eks Pekerja Seks Komersial Lokalisasi Kedung Banteng.

\section{4) Tahap Deklarasi Pemulangan}

Deklarasi pemulangan para WTS lokalisasi Kedung Banteng adalah puncak dari seluruh kegiatan yang telah dipersiapkna sebelumnya. Acara penutupan Lokalisasi Kedung Banteng Kecamatan Sukorejo Kabupaten Ponorogo pada hari senin 8 Juni 2015, dilapangan Desa Kedung Banteng yang dihadiri Oleh Menteri Sosial RI sekaligus menutup seluruh aktifitas lokalisasi untuk kegiatan dan penghunian para WTSnya. Berikut dengan pemulangan para WTS mereka diwajibkan menandatangani fakta Integritas bahwa mereka dilarang untuk melakukan kegiatan Prostitusi di Kabupaten Ponorogo khususnya maupun Jawa Timur pada umumnya. Yang selanjutnya apabila mereka melanggar fakta Integritas tersebut akan diberikan sanksi menurut peraturan Perundang-undangan yang berlaku yang di tuangkan dalam surat pernyataan dengan dilengkapi Materai Rp. 6.000,- (Enam ribu rupiah) dan bagi 
Jurnal Ilmu Pemerintahan: Kajian Ilmu Pemerintahan dan Ilmu Politik, 4 (1), April

2019 - 9

Dian Suluh Kusuma Dewi 1) *, Yusuf Adam Hilman 2)

WTS yang dipulangkan diberikan dana kompensasi sebesar Rp. 5.050 .000 (Lima juta lima puluh ribu rupiah)

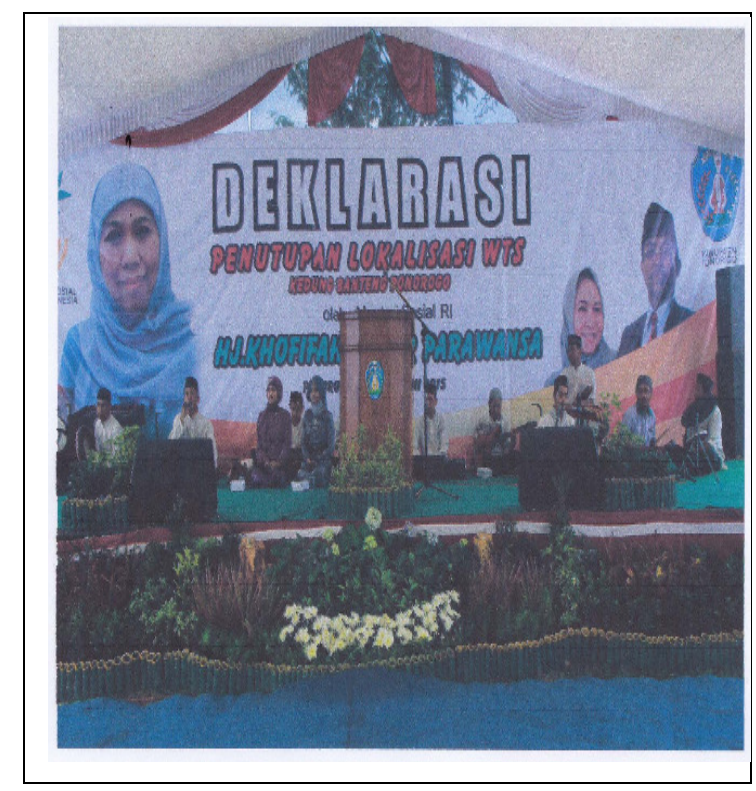

Gambar 6. Deklarasi Pemulangan eks Pekerja Seks Komersial Lokalisasi Kedung Banteng.

\section{5) Tahap Pengosongan.}

Pengosongan Lokalisasi dinyatakan / diharuskan para WTS, penghuni meninggalkan tempat huniannya tersebut pada tanggal 16 Juni 2015, dengan demikian maka Lokalisasi WTS Kedung Banteng Kabupaten Ponorogo sejak tanggal tersebut dinyatakan tidak diperbolehkan untuk dijadikan tempat transaksi prostitusi. Selain pengosongan Lokalisasi dari para WTS yang bekerja sebagai PSK di Lokalisasi tersebut juga dilakukan sterilisasi dari benda-benda atribut maupun simbolsimbol prostitusi/seksual yang memicu kearah perbuatan prostitusi.

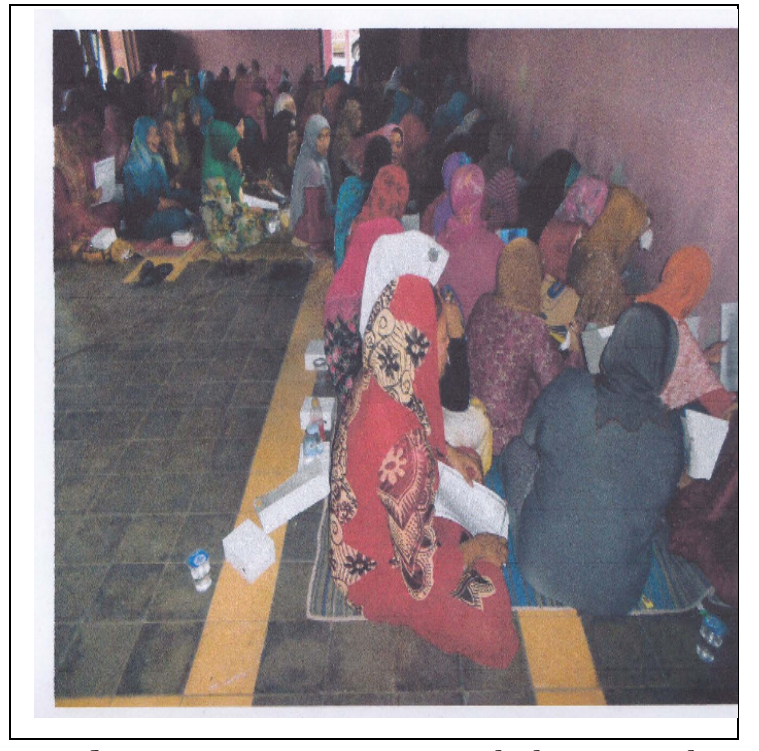

Gambar 7. Pengosongan Lokalisasi Kedung Banteng.

Model penerapan dalwah bil hikmah yaitu dengan rnernposisikan mereka (PSK) sebagai layaknya manusia normal adalah sangat tepat dalam menunjang keberhasilan dakwah dan Pendekatan dakwah yang dapat dipertimbangkan untuk dipilih sebagai pendekatan dakwah terhadap PSK adalah dengan pembinaan mental spiritual dan pemberian ketrampilan sesuai dengan keinginan dan potensi mereka.(A. Sunarto 2011)

\section{Dampak Sosiologis}

Guna mengetahui perkembangan situasi kawasan Lokalisasi Kedung Banteng pasca penutupan, maka perlu dilakukan monitoring serta evaluasi yang selanjutnya untuk direncanakan langkah berikutnya disesuaikan dengan keperluan kedepan menyangkut pemanfaatan lokasi /lahan Lokalisasi.

Tetapi berdasarkan fakta dilapangan secara umum masih banyak permasalahan khususnya pasca penutupan akibat dampak dari penutupan Lokalisasi tersebut, baik tindak lanjut dari pihak PEMDA yang kurang siap menghadapi 


\section{Dian Suluh Kusuma Dewi 1) *, Yusuf Adam Hilman 2)}

dampak-dampak yang ditimbulkan sebagai akibat dari agenda ini ataupun kondisi Lokalisasi yang terkena dampak baik dari segi ekonomi dan sosialnya yang dampak positifnya yang masih jauh dari harapan di bandingkan dampak negativenya. Memang secara teoritis penutupan ini berdampak positif bagi masyarakat sekitar khususnya warga ponorogo dengan tertutupnya salah satu pintu perilaku yang negatif menurut agama dan norma yang berlaku. Tetapi pada kenyataan lapangannya, ini tidak sesuai dengan apa yang diharapkan, terbukti dengan belum adanya tindak lanjut yang signifikan terhadap mereka yang menjadi sasaran kebijakan, dinas yang terkait bekerja sama dengan lembaga lain hanya sebatas memantau keadaan pasca penutupan lokalisasi, hal ini di sebabkan belum adanya instruksi dari pemerintah kabupaten dan pemerintah provinsi.

Salah satu akibat yang cukup memprihatinkan dari pernyataan di atas yang menjadi permasalan yaitu ada dari mereka yang menjual barang-barang mereka, serta aset yang dimiliki agar mereka bisa bertahan hidup, tapi ada juga yang pergi keluar dari tempat tersebut untuk bekerja. Selain itu, pelatihan yang telah mereka dapatkan salah satunya ekonomi produksi usaha pengrajin kerupuk tidak mereka maksimalkan, hal ini disebabkan karena mereka yang tidak mau dan tidak mampu menerapkan pelatihan tersebut dalam mencari mata pencaharian lain, mungkin hal ini kurangnya pembekalan baik itu dari segi keahlian ataupun moralnya.

Selain itu dari segi sosial, meskipun sudah dibekali oleh ketrampilan khusus, namun beberapa eks psk kedung banteng mangaku tidak bias malanjutkan dan menjadikan ketrampilan sebagai mata pencaharian. Karena, beberapa eks psk kedungbanteng mengaku kesulitan dalam memasarkan hasil ketrampilan serta hasil yang diperoleh tidak bisa mencukupi kebutuhan mereka sehari-hari.

Sehingga dampak yang saat ini terlihat jelas adalah dengan maraknya modus prostitusi ilegal dengan menggunakan jasa warung kopi. Warung Kopi di beberapa tempat seperti di Kecamatan Siman, Kecamatan Balong, Kecamatan Danyang, dan di sekitar Kantor Pelayanan Terpadu. Warung kopi di beberapa tempat tersebut memiliki bilik yang digunakan untuk praktek prostitusi. Selain itu, pedagang kopi juga mempersilahkan pelanggannya apabila pelanggan ingin melakukannya di luar warung seperti di hotel.

\section{SIMPULAN DAN SARAN}

\section{Simpulan}

Pelaksanaan penutupan lokalisasi kedung banteng di dasarkan pada kebijakan gubernur dan peraturan bupati, yaitu: 1). SK tanggal 20 Oktober 2011, No: 460/031/2011; Perihal Penanganan Lokalisasi WTS di Jawa Timur. 2). Peraturan Bupati Nomor 1 Tahun 2015 tentang penutupan Lokalisasi WTS di Desa Kedung Banteng, Kecamatan Sukorejo, Kabupaten Ponorogo

Pelaksanaan Penutupan lokalisasi melalui beberapa proses, diantaranya: 1).Tahap Identifikasi, Tahap Sosialisasi dan kordinasi, 3). Tahap Pemberdayaan, 4). Tahap Deklarasi Pemulangan, 5) Tahap Pengosongan. Secara umum proses penutupan lokalisasi sudah berhasil dilaksanakan, akan tetapi dampak dari penutupan lokalisasi terhadap eks PSK menjadi semakin tidak terkendali dan 
Dian Suluh Kusuma Dewi 1) *, Yusuf Adam Hilman 2)

meluas, dikarenakan faktor ekonomi menjadi sumber persoalan yang hingga saat ini belum selesai.

Pelaksanaan kebijakan tersebut telah banyak merubah wilayah tersebut, dari citra negatif kearah yang lebih baik, hal tersebut secara psikologis juga mempengaruhi kehidupan eks para pekerja seks komersil yang kemudian secara perlahan dapat memulai kehidupan baru, membuka usaha baru, dan dapat di terima oleh lingkungan mereka, sehingga banyak merubah kehidupan masyarkaat sekitar.

\section{Saran}

Kami memberikan masukan, supaya proses pendampingan eks - pekerja seks komersil kedung banteng, harus dilakukan secara berkesinambungan supaya ada proses feedback, kemudian dibuatkan program normalisasi kehidupan sosial kemasyarakat di lingkungannya, supaya tidak menimbulkan persoalan baru di kemudian hari, ketika para eks pekerja kembali di lingkungan masyarakat.

\section{DAFTAR PUSTAKA}

A. Sunarto, 2011. Dakw ah pada pekerja seks komersial. kOMUNIKASI iSLAM, 01(01), pp.1-15. Available at: http://jki.uinsby.ac.id/index.php/jki/arti cle/view/91/68.

Achmad Faizal. (2015). Lokalisasi Prostitusi Kedung Banteng Ponorogo Ditutup. Kompas.com.

https://regional.kompas.com/read/2015/ 06/08/18333311/Lokalisasi.Prostitusi.K edung.Banteng.Ponorogo.Ditutup.

diakses pada 11 Agustus 2018.

Arista, R. et al., 2017. Peran Perangkat Desa dan Kecamatan terhadap Pengendalian Peningkatan Seks Bebas Melalui Keberadaan Warung Kopi ( Studi
Kasus di Kabupaten Jember ) ( The Role of Village and Subdistrict Staff in Controlling The Enhancement of Free Sex Through The Existence. Pustaka Kesehatan, 5(2), pp.199-205. Available at: https://jurnal.unej.ac.id/index.php/JPK/ article/view/5488/4113.

Ati, N.U. et al., 2015. Empowerment Model For Adolescents Fallen Into Prostitution In Theregency Of Malang. Pelopor, 9(1), pp.105-132. Available at:

http://riset.unisma.ac.id/index.php/fia/a rticle/view/172.

Dili Eyato. (2015). Lokalisasi Kedung Banteng, Ponorogo Ditutup. Sindonews. https://nasional.sindonews.com/read/10 10525/149/lokalisasi-kedung-bantengponorogo-ditutup-1433821952. diakses pada 11 Agustus 2018.

Dita Fatika Sari, M.F.M., 2011. Proses Pemberdayaan Bagi Warga Terdampak Penutupan Lokalisasi Dolly Di Kelurahan Putat Jaya Kecamatan Sawahan Surabaya PROSES Pemberdayaan Bagi Warga Terdampak Penutupan Surabaya Proses Pemberdayaan Bagi Warga Terdampak Penutupan Lokalisasi Dolly Di Kelur. Publika, 4(3), pp.1-7.

Gunawan Prakoso, Ani Purwanti, D.W., 2016. Gunawan Prakoso *, Ani Purwanti , Dyah Wijaningsih merupakan Pemrintah Daerah kabupaten Belitung dalam. Diponegoro Law Journal, 5(4), pp.1-17. Available at:

https://ejournal3.undip.ac.id/index.php/ dlr/article/view/12771/12382.

Hasneli, 2015. Pembinaan Kesehatan Mental terhadap Eks Wanita Tuna Susila. UNISIA, XXXVII(82), pp.4856.

Irwandy Samad, 2012. Pelacuran dalam Perspektif Kriminalistik. Lex Crimen, 1(4), pp.60-78. Available at: https://ejournal.unsrat.ac.id/index.php/l 
Jurnal Ilmu Pemerintahan: Kajian Ilmu Pemerintahan dan Ilmu Politik, 4 (1), April

2019 - 12

Dian Suluh Kusuma Dewi 1) *, Yusuf Adam Hilman 2)

excrimen/article/view/902/717.

M. Zainuddin, 2016. Kajian Dampak Kebijakan Penutupan Lokalisasi Teleju Oleh Pemerintah Kota Pekanbaru. Ilmu Pemerintahan Nahkoda, 15(26), pp.7888. Available at: https://ejournal.unri.ac.id/index.php/JIP N/article/view/3846/3738.

Miwa Patnani, 1999. Prostitusi : antara Pilihan dan Keterpaksaan. Kognisi, 3(2), pp.57-60. Available at: http://journals.ums.ac.id/index.php/indi genous/article/view/4603/2992.

Nida Issabela, W.H., 2010. Resiliensi pada Keluarga yang Tinggal di Lingkungan. Jurnal Insan Media Psikologi, 12(03), pp.176-186. Available at: journal.unair.ac.id.

Permadi, A.S., 2015. Permadi, Aad Satria, Available at: https://publikasiilmiah.ums.ac.id/bitstre am/handle/11617/6511/1-Aad Satria Permadi.pdf? sequence $=1$.

Supriyadi Widodo Eddyono, Rio Hendra, A.A.B., 2017. Melawan Praktik Prostitusi Anak di Indonesia dan Tantangannya, Instutite for Criminal Justice Reform. Available at: http://icjr.or.id.

Tri Yanuar Ahmad, 2014. sebagai Media Promosi Band Myviolaine Morning. Universitas Sultan Ageng Tirtayasa. Available at: http://repository.fisipuntirta.ac.id/387/1/KOM - Pemanfaatan Jejaring Sosial Soundcloud Sebagai Media Promosi Band My Violaine Morning.pdf.

Vive Vike Mantiri, 2014. Prilaku Menyimpang di Kalangan Remaja di Kelurahan Pondang, Kecamatan
Amurang Timur Kabupaten Minahasa Selatan. Acta Diurna, III(1), pp.1-13. Available at: https://ejournal.unsrat.ac.id/index.php/a ctadiurna/article/view/4476/4003.

Zen Arivin. (2016). Dari 47 Lokalisasi di Jatim, Balongcangkring yang Terakhir Ditutup. Okezone news. https://news.okezone.com/read/2016/05 /29/519/1400741/dari-47-lokalisasi-dijatim-balongcangkring-yang-terakhirditutup diakses pada 11 Agustus 2018.

\section{Profil Penulis}

Penulis Pertama bernama Dian Suluh Kusuma Dewi, Kelahiran Ponorogo, saat ini sedang menempuh program doktoral Politik Islam di Universitas Muhammadiyah Yogyakarta, kajian kajian nya fokus di bidang komunikasi Politik dan juga Politik Kebijakan, saat ini tercatans ebagai Dosen Program Studi Ilmu Pemerintahan Universitas Muhammadiyah Ponorogo.

Penulis Kedua bernama Yusuf Adam Hilman, saat ini menjabat sebagai sekertariis Program Studi Ilmu Pemeirntahan FISIP, Universitas Muhammadiyah Ponorogo, beliau fokus pada kajian - kajian sosiologis. 